\section{Bronchoalveolar lavage with trypsin in pulmonary alveolar proteinosis}

\author{
Yukio Nagasaka, Mika Takahashi, \\ Hisao Ueshima, Yuji Tohda, \\ Sigenori Nakajima
}

\begin{abstract}
Two cases of pulmonary alveolar proteinosis were treated with bronchoalveolar lavage (BAL) via a fibreoptic bronchoscope. Additional clinical improvement was seen when trypsin was added to the lavage fluid. Analysis of effluents in the BAL fluid showed marked reduction of protein constituents with clinical improvement after treatment with trypsin in the lavage. BAL with trypsin was well tolerated.
\end{abstract}

(Thorax 1996;51:769-770)

Department of

Medicine,

Kinki University

School of Medicine,

377-2 Ohnohigashi,

Osakasayama,

Osaka, Japan

Y Nagasaka

M Takahashi

H Ueshima

Y Tohda

S Nakajima

Correspondence to: Dr Y Nagasaka.

Received 17 January 1995 Returned to authors

23 March 1995

Revised version received

5 April 1995

Accepted for publication

21 July 1995
Keywords: bronchoalveolar lavage, trypsin, pulmonary alveolar proteinosis.

Bronchoalveolar lavage (BAL) is a recognised treatment for pulmonary alveolar proteinosis (PAP). Lavage of an entire lung may be performed under general anaesthesia. ${ }^{1-3}$ This procedure may be associated with severe hypoxaemia. ${ }^{4}$ Inhalation of proteolytic enzymes has been tried in PAP with some benefit but is associated with allergic reactions. ${ }^{5-7}$ We performed BAL with trypsin added to the lavage fluid using a fibreoptic bronchoscope in two patients with PAP.

\section{Case reports}

CASE 1

A 45 year old man presented with a history of progressive breathlessness lasting a few months. Corticosteroid therapy had no benefit so he was referred for further management. There was no occupational history. The patient was dyspoeic and cyanosed, and the chest radiograph showed diffuse alveolar infiltrates predominantly in the perihilar region (figure). Pulmonary function tests showed a restrictive ventilation defect with impaired single breath gas transfer factor. Chemical analysis of the blood revealed increased levels of lactate dehydrogenase $(\mathrm{LDH})$ and carcinoembryonic antigen (CEA). The diagnosis of PAP was made by fibreoptic bronchoscopy.

Treatment with BAL was then commenced with the fibreoptic bronchoscope placed in a segmental or lobar bronchus under local anaesthesia and was repeated weekly. An aliquot of $50 \mathrm{ml}$ of warmed and heparinised saline was injected, suctioned, and the aliquot repeated until the patient became uncomfortable with the procedure or the total fluid instilled reached $1000 \mathrm{ml}$. For the initial seven lavages in which trypsin was not used a mean (SD) of 717 $(190 \cdot 1) \mathrm{ml}$ of heparinised saline was used and the recovery rate was $69(5 \cdot 9) \%$. Radiographic and physiological improvement was considered inadequate (table, figure), and nine subsequent lavages included 40000 USP units of bovine trypsin (Trypsilin, Mochida Pharmaceutical, Tokyo, Japan) per $1000 \mathrm{ml}$ of heparinised saline. A mean (SD) volume of $927(85.4) \mathrm{ml}$ of lavage fluid was used and the recovery rate was $68(7 \cdot 7) \%$. After trypsin was added, protein and phospholipid concentrations of the lavage effluent increased and radiographic and physiological improvement followed (table, figure). The total duration of treatment was four months and the patient was well one year after treatment with pulmonary function tests nearly normal.

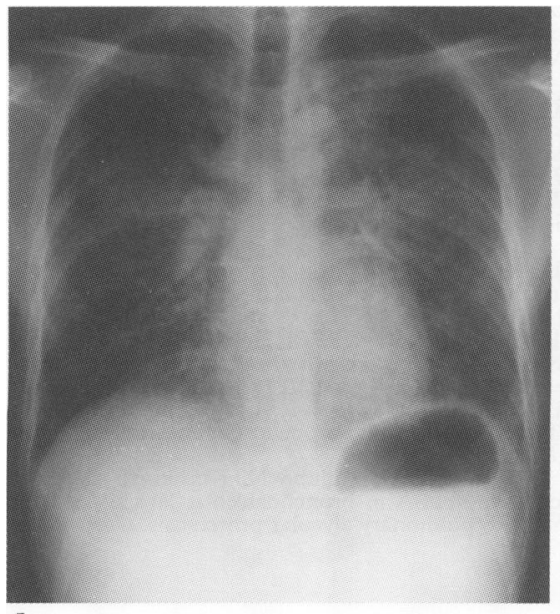

A

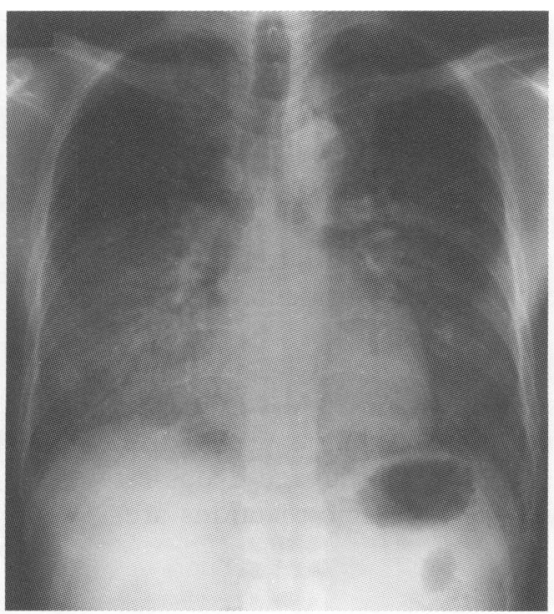

B

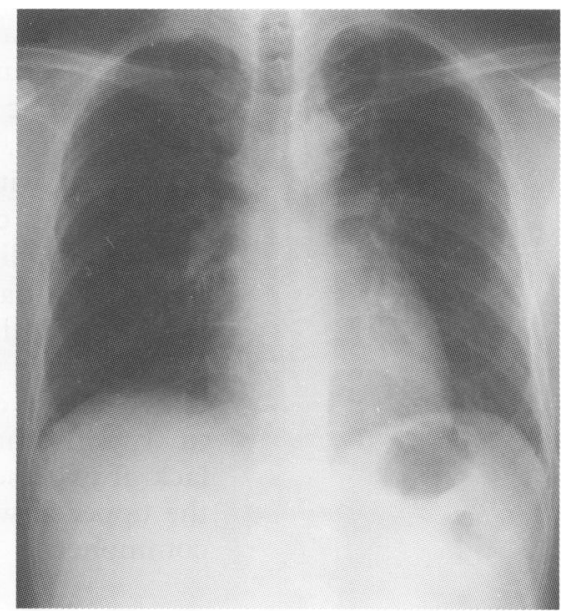

C

Posteroanterior chest radiographs of case $1(A)$ before lavage, $(B)$ after lavage seven times without trypsin, and (C) after lavage nine times with trypsin showing minimal improvement of diffuse pulmonary infiltrate after seven lavages without trypsin and almost complete clearing after nine lavages with trypsin. 
Effect of bronchoalveolar lavage (BAL) on pulmonary function, arterial blood gases, and blood chemistry and protein and lipid constituents of lavage effluent in patient 1

\begin{tabular}{|c|c|c|c|c|c|c|}
\hline & $\begin{array}{l}\text { Before } \\
\text { lavage* }\end{array}$ & $\begin{array}{l}\text { After lavage without } \\
\text { trypsin ( } 7 \text { times) }\end{array}$ & $\begin{array}{l}\text { After lavage with } \\
\text { trypsin ( } 2 \text { times) }\end{array}$ & $\begin{array}{l}\text { After lavage with } \\
\text { trypsin (9 times) }\end{array}$ & $\begin{array}{l}\text { Four months } \\
\text { later }\end{array}$ & $\begin{array}{l}13 \text { months } \\
\text { later }\end{array}$ \\
\hline $\begin{array}{l}\text { FVC (ml) } \\
\% F V C \\
\text { TLC (ml) } \\
\% T L C \\
\text { TLCo }(\mathrm{mmol} / \mathrm{min} / \mathrm{kPa}) \\
\% \mathrm{TLCO} \\
\mathrm{PaO}_{2}(\mathrm{kPa}) \\
\mathrm{LDH}^{* *}(\mathrm{U} / \mathrm{ml}) \\
\mathrm{CEA}(\mathrm{mg} / \mathrm{ml})\end{array}$ & $\begin{array}{c}2120 \\
58 \\
2680 \\
46 \\
2 \cdot 88 \\
45 \\
7 \cdot 1 \\
642 \\
7 \cdot 8\end{array}$ & $\begin{array}{c}2230 \\
61 \\
2860 \\
50 \\
2 \cdot 71 \\
42 \\
5 \cdot 6 \\
469 \\
8 \cdot 0\end{array}$ & $\begin{array}{c}2310 \\
63 \\
3420 \\
60 \\
2 \cdot 71 \\
42 \\
7 \cdot 2 \\
486 \\
5 \cdot 7\end{array}$ & $\begin{array}{c}2300 \\
63 \\
3440 \\
60 \\
3 \cdot 69 \\
61 \\
12 \cdot 1 \\
345 \\
2 \cdot 4\end{array}$ & $\begin{array}{c}2640 \\
72 \\
3860 \\
67 \\
5 \cdot 66 \\
83 \\
14 \cdot 1 \\
285 \\
\text { n.t. }\end{array}$ & $\begin{array}{c}2870 \\
79 \\
3930 \\
69 \\
5 \cdot 76 \\
84 \\
12 \cdot 9 \\
261 \\
\text { n.t. }\end{array}$ \\
\hline $\begin{array}{l}\text { Analysis of BAL fluid } \\
\text { Total protein (mg/ml) } \\
\text { LDH (U/ml) } \\
\text { CEA (mg/ml) } \\
\text { Phospholipid (nmol/ml) } \\
\text { SP-A (mg/ml) }\end{array}$ & $\begin{array}{c}13 \cdot 7 \\
746 \\
125 \cdot 0 \\
5233 \\
3.5\end{array}$ & $\begin{array}{c}6 \cdot 2 \\
740 \\
71 \cdot 4 \\
186 \\
0.4\end{array}$ & $\begin{array}{c}9 \cdot 8 \\
\text { n.t. } \\
\text { n.t. } \\
2746 \\
3 \cdot 2\end{array}$ & $\begin{array}{c}1 \cdot 1 \\
267 \\
42 \cdot 1 \\
0 \\
0 \cdot 1\end{array}$ & $\begin{array}{l}\text { n.t. } \\
\text { n.t. } \\
\text { n.t. } \\
\text { n.t. } \\
\text { n.t. }\end{array}$ & $\begin{array}{l}\text { n.t. } \\
\text { n.t. } \\
\text { n.t. } \\
\text { n.t. } \\
\text { n.t. }\end{array}$ \\
\hline
\end{tabular}

* For BAL fluid the data were from the first BAL.

** Normal value for blood LDH is $100-225 \mathrm{IU} / 1$.

$\mathrm{FVC}=$ forced vital capacity; TLC $=$ total lung capacity; TLCO = carbon monoxide transfer factor; $\mathrm{PaO}_{2}=$ arterial oxygen tension; $\mathrm{LDH}=$ lactate dehydrogenase; $\mathrm{CEA}=$ carcinoembryonic antigen; SP-A = surfactant protein A; n.t. = not tested.

CASE 2

A 50 year old arc welder who noted increasing dyspnoea and a non-productive cough was diagnosed as having PAP by fibreoptic bronchoscopy. Trypsin inhalation by ultrasonic nebuliser (100000 units of trypsin in $20 \mathrm{ml}$ of saline for 20 minutes twice daily for three months) did not improve the chest radiograph or arterial blood gas tensions. After repeated segmental or lobar BAL with trypsin (40000 units per $1000 \mathrm{ml}$ of saline) 11 times during a four month period, $\mathrm{PaO}_{2}$ increased from $7 \cdot 1$ to $11.7 \mathrm{kPa}$. Two and 13 years after discharge pulmonary function, arterial blood gas tension, and chest radiographs were normal. Analysis of BAL fluid was not performed.

\section{Discussion}

Segmental lavage using fibreoptic bronchoscopy has been used for diagnostic purposes ${ }^{8}$ but reports of its therapeutic use have been limited. ${ }^{9}$ We were not able to find any report describing the use of proteolytic enzyme for lavage in the treatment of PAP.

Arora and colleagues reported temporary clinical improvement but with allergic reactions following parenteral or inhaled trypsin in three cases ${ }^{6}$ while another case treated with trypsin inhalation underwent clinical resolution. ${ }^{5}$ These allergic reactions were treated with an antihistamine. Riker reported clinical improvement with aerosolised trypsin. ${ }^{7}$ In all of these reports copious sputum production was followed by clinical improvement after inhaled trypsin, but patients are likely to become sensitised to trypsin.

No allergic reaction to trypsin was seen in either of our cases who may be less sensitive to trypsin than others. Another cause of the lack of hypersensitivity is that lavage bypasses the upper airways where allergic reactions are commoner.
Case 1 showed little objective improvement with conventional BAL. The patient improved after trypsin had been added to the lavage fluid and tolerated the procedure well. With supplemental oxygen during BAL there was no hypoxaemia as defined by an oxygen saturation of less than $85 \%$ by fingertip oximetry.

In case 1 analysis of the lavage revealed increased protein components. ${ }^{10}$ Without trypsin, the protein concentration of the lavage effluent decreased while physiological improvement was small. With trypsin in the lavage fluid, protein and phospholipid concentrations of the lavage effluent increased again and then decreased along with a physiological and clinical improvement.

In the two cases reported here alveolar lavage using trypsin in saline was effective, with no recurrence being noted at 13 years in one case. We conclude that lobar lavage with trypsin is worth assessing in a larger number of patients.

The authors thank Drs Yoshio Kuroki and Toyoaki Akino of the Department of Biochemistry of Sapporo Medical College for measurement and analysis of the lavage effluents.

1 Kao D, Wasserman K, Costley D, Benfield JR. Advances in the treatment of pulmonary alveolar proteinosis. $\mathrm{Am}$ Rev Respir Dis $1975 ; 111: 361-3$.

2 Rogers RM, Levin DC, Gray BA, Moseley Jr. LW. Physiologic effect of bronchopulmonary lavage in alveolar prologic effect of bronchopulmonary lavage in al

3 Claypool WD, Rogers RM, Matuschak GM. Update on the clinical diagnosis, management, and pathogenesis of pulmonary alveolar proteinosis (phospholipidosis). Chest 1984;85:550-8

4 Altose Md, Hicks RE, Edwards MW. Extracorporeal membrane oxygenation during bronchopulmonary lavage. Arch Surg 1976;111:1148-53.

5 Brodsky I, Mayock RL. Pulmonary alveolar proteinosis, remission after therapy with trypsin and chymotrypsin. $N$ Engl F Med 1961;265:935-8.

6 Arora PL, Rogers RM, Mayock RL. Alveolar proteinosis, experience with trypsin therapy. Am $\mathcal{F}$ Med 1968;44:88999.

7 Riker JB, Wolinsky H. Trypsin aerosol treatment of pulmonary alveolar proteinosis. Am Rev Respir Dis 1973;108: 108-13.

8 Martin RJ, Coalson JJ, Rogers RM, Horton FO, Manous LE Pulmonary alveolar proteinosis: the diagnosis by segmenta lavage. Am Rev Respir Dis 1980;121:819-25.

9 Brach BB, Harrel JH, Moser KM. Alveolar proteinosis: lobar lavage by fiberoptic bronchoscope technique. Chest 1980;69:224-5

10 Honda Y, Takahashi H, Shijubo N, Kuroki Y, Akino T Surfactant protein-A in bronchoalveolar lavage fluids of patients with pulmonary alveolar proteinosis. Chest 1993; 103:496-9. 